University of Nebraska - Lincoln

DigitalCommons@University of Nebraska - Lincoln

Faculty Publications from the Harold W. Manter Laboratory of Parasitology

4-2005

Parhadjelia cairinae n. sp. (Nematoda: Habronematoidea: Habronematidae) in the Muscovy Duck, Cairina moschata (Linnaeus, 1758) (Aves: Anseriformes: Anatidae), from the Área de Conservación Guanacaste, Costa Rica

Luping Zhang

University of Toronto

Daniel R. Brooks

University of Toronto,dnlbrooks@gmail.com

Follow this and additional works at: https://digitalcommons.unl.edu/parasitologyfacpubs

Part of the Parasitology Commons

Zhang, Luping and Brooks, Daniel R., "Parhadjelia cairinae n. sp. (Nematoda: Habronematoidea: Habronematidae) in the Muscovy Duck, Cairina moschata (Linnaeus, 1758) (Aves: Anseriformes: Anatidae), from the Área de Conservación Guanacaste, Costa Rica" (2005). Faculty Publications from the Harold W. Manter Laboratory of Parasitology. 224.

https://digitalcommons.unl.edu/parasitologyfacpubs/224

This Article is brought to you for free and open access by the Parasitology, Harold W. Manter Laboratory of at DigitalCommons@University of Nebraska - Lincoln. It has been accepted for inclusion in Faculty Publications from the Harold W. Manter Laboratory of Parasitology by an authorized administrator of DigitalCommons@University of Nebraska - Lincoln. 


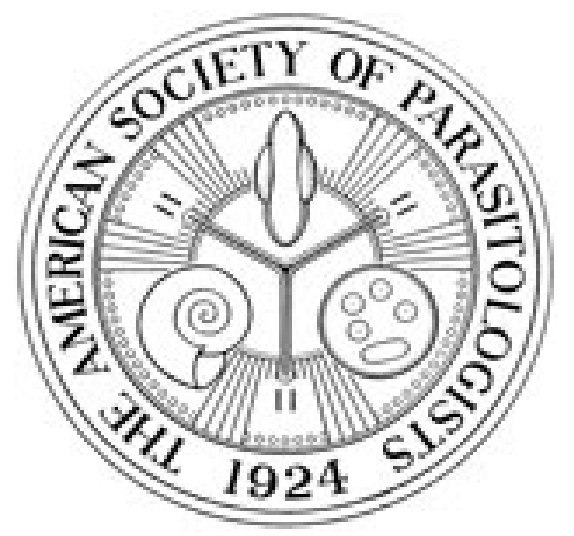

Parhadjelia cairinae n. sp. (Nematoda: Habronematoidea: Habronematidae) in the Muscovy Duck, Cairina Moschata (Linnaeus, 1758) (Aves: Anseriformes: Anatidae), from the Area De Conservacion Guanacaste, Costa Rica Author(s): Luping Zhang and Daniel R. Brooks

Source: The Journal of Parasitology, Vol. 91, No. 2 (Apr., 2005), pp. 438-440

Published by: The American Society of Parasitologists

Stable URL: http://www.jstor.org/stable/3286443

Accessed: 24/04/2010 01:23

Your use of the JSTOR archive indicates your acceptance of JSTOR's Terms and Conditions of Use, available at http://www.jstor.org/page/info/about/policies/terms.jsp. JSTOR's Terms and Conditions of Use provides, in part, that unless you have obtained prior permission, you may not download an entire issue of a journal or multiple copies of articles, and you may use content in the JSTOR archive only for your personal, non-commercial use.

Please contact the publisher regarding any further use of this work. Publisher contact information may be obtained at http://www.jstor.org/action/showPublisher?publisherCode=asp.

Each copy of any part of a JSTOR transmission must contain the same copyright notice that appears on the screen or printed page of such transmission.

JSTOR is a not-for-profit service that helps scholars, researchers, and students discover, use, and build upon a wide range of content in a trusted digital archive. We use information technology and tools to increase productivity and facilitate new forms of scholarship. For more information about JSTOR, please contact support@ jstor.org.

The American Society of Parasitologists is collaborating with JSTOR to digitize, preserve and extend access to The Journal of Parasitology. 


\title{
PARHADJELIA CAIRINAE N. SP. (NEMATODA: HABRONEMATOIDEA: HABRONEMATIDAE) IN THE MUSCOVY DUCK, CAIRINA MOSCHATA (LINNAEUS, 1758) (AVES: ANSERIFORMES: ANATIDAE), FROM THE AREA DE CONSERVACION GUANACASTE, COSTA RICA
}

\author{
Luping Zhang and Daniel R. Brooks \\ Centre for Comparative Biology and Biodiversity, Department of Zoology, University of Toronto, Ontario M5S 3G5, Canada. e-mail: \\ dbrooks@zoo.utoronto.ca
}

\begin{abstract}
A new species of Parahadjelia occurs in the muscovy duck, Cairina moschata (Linnaeus, 1758), from the Area de Conservacion Guanacaste, Costa Rica. The new species differs from Parhadjelia neglecta Lent and Freitas, 1939, in the body size, in the spicules shape and ratio of spicules, and in having 2 pairs of sessile papillae near the tail tip of the male. The characters exhibited by $P$. neglecta and the new species validate its generic status distinct from Hadjelia.
\end{abstract}

Habronematid nematodes have been reported living under the lining of the gizzard of avian hosts throughout the world. Previously, we reported 6 species representing 3 habronematid genera (Procyrnea Chabaud, 1958; Excisa Gendre, 1928; Torquatoides Williams, 1929) inhabiting avian hosts from the Area de Conservacion Guanacaste (ACG), Costa Rica (Zhang and Brooks, 2004; Zhang et al., 2004). On 20 May 2003, as part of an ongoing biodiversity inventory of the eukaryotic parasites of vertebrates inhabiting the ACG in northwestern Costa Rica (http://brooksweb.zoo.utoronto.ca/index.html), we collected specimens of a previously undescribed species of the rarely reported and unusual Parhadjelia Lent and Freitas, 1939.

\section{MATERIALS AND METHODS}

The host, a muscovy duck, Cairina moschata (Linnaeus, 1758), was collected on 20 May 2003 and examined for parasites. Nematodes collected from beneath the lining of the gizzard were fixed in glacial acetic acid and preserved and stored in $70 \%$ ethanol. They were later cleared in lactophenol for further examination. Drawings were made with microscopy tube. Measurements (minimum, maximum, with mean in parentheses) were given in micrometers $(\mu \mathrm{m})$ unless otherwise stated. $\mathrm{TBL}=$ total body length.

\section{DESCRIPTION}

Parhadjelia cairinae n. sp. (Figs. 1-9)

Diagnosis: Body elongated, slender and medium size with fine transverse striations. Lateral alae absent. Oral opening dorsoventrally elongated and laterally compressed and dumbbellshaped. Lateral pseudolabia well developed, each pseudolabium bearing cuticular thickened edges on anterior and posterior borders. Two papillae on anterior end and 1 amphid on posterior end of each pseudolabium. Dorsal and ventral labia deeply notched in median line, with 2 labial papillae and 2 large cephalic papillae located on each median labium. Two internal processes extending dorsally and ventrally from median line of dorsal and ventral labia respectively, each consisting of 2 sword-shaped structures (Fig. 1). Two triangular wings located on dorsal and ventral sides of each pseudolabium. Buccal capsule short and cylindrical. Esophagus clearly divided into short anterior muscular part and long posterior glandular part. Mus-

Received 30 October 2003; revised 2 August 2004; accepted 2 August 2004.

* To whom correspondence should be addressed. cular esophagus $5.1 \%$ TBL in male and $3.7-5.0 \%$ (4.2\%) TBL in female; glandular esophagus $36.8 \%$ TBL in males and $24.5-$ $28.4 \%(26.4 \%)$ TBL in females. Nerve ring located at anterior part of muscular esophagus. Cervical papillae and excretory pore immediately posterior to nerve ring.

Male $(n=1)$ : Body length $4.64 \mathrm{~mm}$. Maximum width 143 . Buccal capsule 26 long. Muscular esophagus 238 long and 22 wide; glandular esophagus 1,700 long and 51 wide. Nerve ring 200 from anterior end; excretory pore 254 from anterior end; cervical papillae 222 from anterior end. Posterior end of body curved. Caudal alae well developed and asymmetrical, 269 long; left ala 54 wide, right ala 38 wide. Tail rounded, 109 long. Tail with 4 pairs of preanal pedunculate papillae, 2 pairs of postanal pedunculate papillae, 2 pairs of small sessile papillae near tail tip. Spicules unequal and similar-shaped, with rounded proximal and pointed distal ends. Left spicule 1,130 long, right spicule 238 long. Ratio of right:left spicules 1:4.7. Gubernaculum absent.

Female $(n=5)$ : Body length 5.93-7.16 mm $(6.61 \mathrm{~mm})$. Maximum width 159-190 (170). Buccal capsule 31-37 (34) long. Muscular esophagus 254-317 (275) long, and 25-32 (28) wide; glandular esophagus 1,450-2,030 (1,750) long, and 5770 (64) wide. Nerve ring 190-216 (205) from anterior end; excretory pore 247-276 (260) from anterior end; cervical papillae 222-250 (236) from anterior end. Vulva located near anterior third of body, $2.12-2.64 \mathrm{~mm}(2.35 \mathrm{~mm})$, or $32.7-36.9 \%$ (35.6\%) TBL, from anterior end. Tail long and rounded, 193 225 (216) long. Eggs ellipsoid, thick-shelled, embryonated, 3543 (40) long, 19-22 (21) wide.

\section{Taxonomic summary}

Type host: Cairina moschata (Linnaeus, 1758) (Aves: Anseriformes: Anatidae).

Type locality: Cafetal, Sector Santa Rosa, Area de Conservacion Guanacaste, Guanacaste Province, Costa Rica, $10^{\circ} 50^{\prime} 44^{\prime \prime} \mathrm{N}, 85^{\circ} 36^{\prime} 26^{\prime \prime} \mathrm{W}$.

Site of infection: Under the lining of the gizzard.

Prevalence: 1/1.

Intensity: One male and 5 females in 1 host.

Type specimens: Holotype: USNPC 95652 (male); Allotype: USNPC 95653 (female); Paratype: USNPC 95654 (4 females).

Etymology: The new species is named after its host genus. 

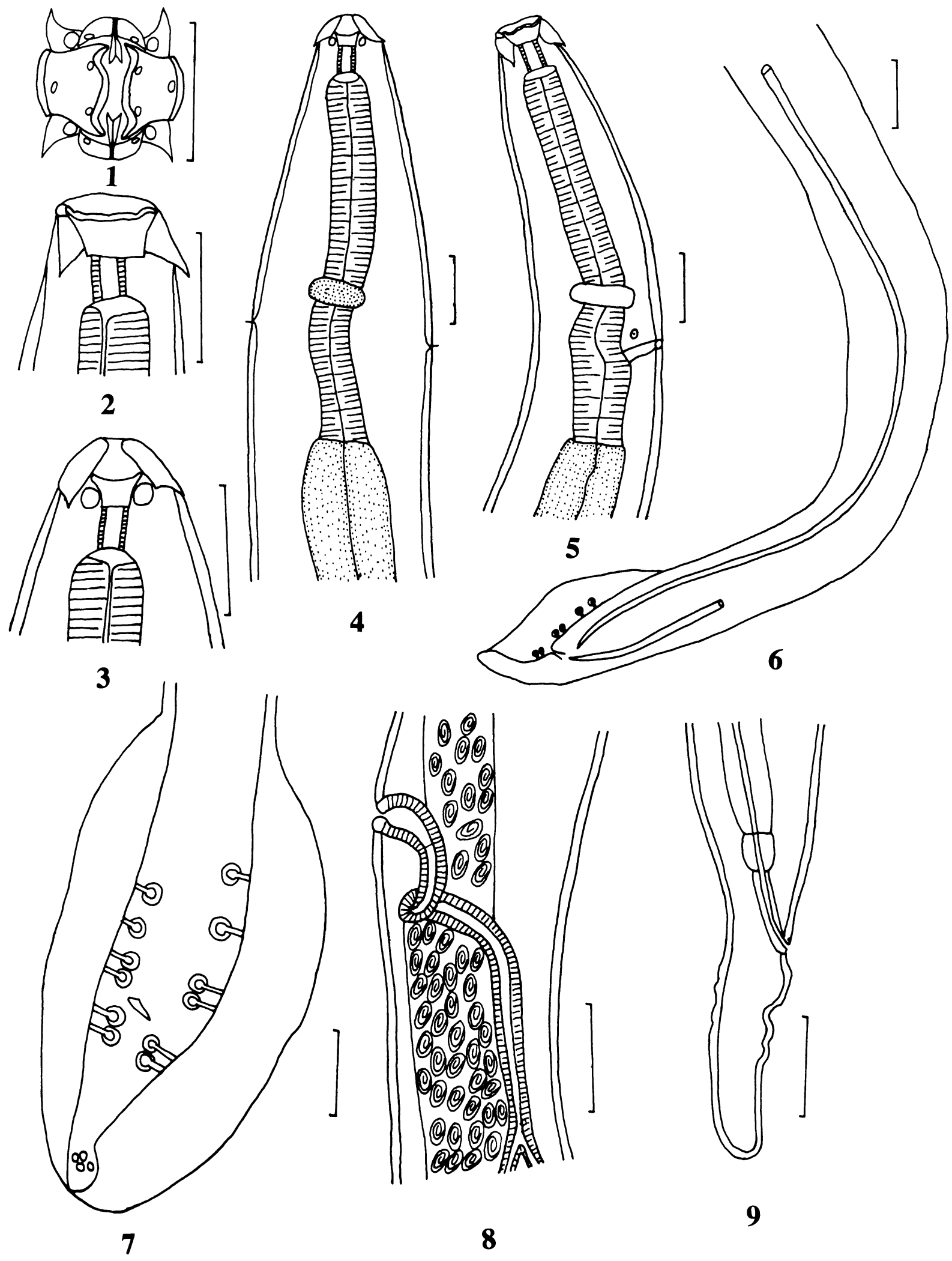

8

9

Figures 1-9. Wonginema cairinae n. sp. 1. Anterior extremity of female, enface view. 2. Anterior end of allotype female, lateral view. 3. Anterior end of allotype female, ventral view. 4. Anterior part of allotype female, ventral view. 5. Anterior end of allotype female, lateral view. 6. Posterior end of holotype male, lateral view. 7. Holotype male tail, ventral view. 8. Vulvar region of allotype female. 9. Posterior end of allotype female, lateral view. 1-5, 7. Bars $=50 \mu \mathrm{m} ; \mathbf{6 , 8}, \mathbf{9}$. Bars $=100 \mu \mathrm{m}$. 


\section{Remarks}

Lent and Freitas (1939) proposed Parhadjelia for a habronematid, P. neglecta, collected in a domestic duck, Anas boschas domestica Linnaeus, from Brazil, which differed from species of Hadjelia in lacking blades on the posterior ends of the pseudolabia, in having 2 lateral wings on each pseudolabium, and in having internal processes. Despite these reported differences, Chabaud (1958/1959) synonymized Parahadljelia with Hadjelia. Subsequently, Yamaguti (1961) considered Parhadjelia a valid genus, whereas Skrjabin and Sobolev (1963) accepted Chabaud's synonymy, which Chabaud (1975) later repeated. Having discovered a second species of habronematid living under the lining of the gizzard of an anatid and exhibiting the same oral morphology as $P$. neglecta, however, we consider Parhadjelia a valid genus.

The new species differs from $P$. neglecta qualitatively by having similar rather than dissimilar spicules and 2 pairs of sessile papillae near the tail tip of male rather than none, having shorter bodies (male $4.64 \mathrm{~mm}$, females $5.93-7.16 \mathrm{~mm}$ in $P$. cairinae vs. males $6.97-9.20 \mathrm{~mm}$, females $11.97-14.99 \mathrm{~mm}$ in P. neglecta), and a spicule ratio of $1: 4.7$ vs. 1:6.14-6.62.

\section{DISCUSSION}

Both species of Parahadjelia are now known to inhabit anatid birds in the Neotropics. We presume, therefore, that $P$. neglecta also occurs in nondomestic anatids in Brazil. Discoveries of species such as $P$. cairinae highlight our essential ignorance of parasite diversity, despite nearly 2 centuries of taxonomic endeavor. This underscores the need to support ongoing inventories of parasite biodiversity, not only for expanding our understanding of the full scope of parasite diversity, but also for clarifying and correcting taxonomic decisions based on as sumptions that the full range of diversity has been circumscribed.

\section{ACKNOWLEDGMENTS}

We are grateful to the scientific and technical staff of the ACG for support of this study, in particular: Elda Araya, Roger Blanco, Carolina
Cano, Maria Marta Chavarría, Felipe Chavarría, Roberto Espinoza, Dunia Garcia, Guillermo Jimenez, Elba Lopez, Sigifredo Marin, Alejandro Masis, Calixto Moraga, Fredy Quesada, and Petrona Rios. Thanks also to Dan Janzen and Winnie Hallwachs, scientific advisers to the ACG, for their support. Host specimens were collected by Douglas Causey and Jeremiah Trimble (Museum of Comparative Zoology, Harvard University) and Calixto Moraga (ACG) under the authority of CITES permits US9258251 and CR9123440, Costa Rica Ministero del Ambiente y Energia Licencia 203640283 and Resoluciones 215-2001OFAU and 411-2001-OFAU, Harvard University IACUC protocol 2109, and USDA APHIS Permit 47956 (form VS16-6A). Host necropsy and parasite collections were made by D.R.B., Douglas Causey, Elda Araya, Sara Brant, Marie Causey, Ben Hanelt, Calixto Moraga, and Petrona Rios. This study was funded by a research grant from the Natural Sciences and Engineering Research Council (NSERC) of Canada to D.R.B. and by a grant from the MCZ Putnam Expedition Fund to Douglas Causey.

\section{LITERATURE CITED}

Chabaud, A. G. 1958/1959. Essai de classification des nematodes Habronematinae. Annales de Parasitologie Humaine et Comparee 33: 445-508.

- 1975. Keys to the genera of the order Spirurida. Part 2. Spiruroidea, Habronematoidea and Acuarioidea. In CIH keys to the nematode parasites of vertebrates. No. 3, R. C. Anderson, A. G. Chabaud, and S. Willmott (eds.). Commonwealth Agricultural Bureaux, Farnham Royal, U.K., p. 29-58.

LENT, H., AND J. F. T. FREITAS. 1939. Novo nematodeo parasito do pato domestico (Spiruroidea). Boletim Biologica 4: 177-180.

SkrJabin, K. I., AND A. A. Sobolev. 1963. Principles of nematology 11. Spirurata of animals and man and the diseases caused by them Part 1. Spiruroidea. Izdatel'stvo Nauka, Moscow, p. 134-184. [In Russian.]

Yamaguti, S. 1961. Systema Helminthum. Vol. III. The nematodes of vertebrates, part I and II. Interscience Publishers, New York, New York, p. 1-1261.

$\rightarrow$ Zhang, L., AND D. R. Brooks. 2004. Torquatoides trogoni n. sp. and Excisa ramphastina n. sp. (Nematoda: Habronematoidea: Habronematidae) in birds from the Area de Conservacion Guanacaste, Costa Rica. Journal of Parasitology 90: 626-630.

$\rightarrow-$ - - AND D. CAuSEY. 2004. Procyrnea Chabaud, 1958 (Nematoda: Habronematoidea: Habronematidae) in birds from the Area de Conservacion Guanacaste, Costa Rica, including descriptions of 3 new species. Journal of Parasitology 90: 364-372. 